UNIVERSITAS MUHAMMADIYAH MATARAM
JURNAL ELEMENTARY
http://journal.ummat.ac.id/index.php/elementary
$2614-5596$ (Online)

\title{
Implementasi model pembelajaran berbasis masalah pada pembelajaran tematik terpadu kurikulum 2013 di kelas tinggi SDN 04 Aikmel
}

\section{H.Muhyi}

Pengawas SD UPTD Kecamatan Aikmel, Lombok Timur h.muhyi@gmail.com

\begin{tabular}{ll}
\hline Informasi artikel & ABSTRAK \\
\hline Sejarah artikel: & Penelitian ini bertujuan untuk mendeskripsikan implementasi Model Pembelajaran \\
Diterima: 28 Mei 2108 & Berbasis Masalah pada pembelajaran tematik terpadu kurikulum 20I3 di kelas \\
Revisi: 03 Juni 2018 & tinggi SDN 04 Aikmel. Jenis penelitian ini adalah penelitian kualitatif. Peneliti \\
Dipublikasikan: 30 Juni 20I8 & mengamati dan mendokumentasikan proses kegiatan pembelajaran menggunakan \\
\hline Kata kunci: & model pembelajaran berbasis masalah pada kelas tinggi SDN 04 Aikmel. Teknik \\
Pembelajaran berbasis masalah & analisis data yang digunakan dalam penlitian ini adalah menggunakan teknik model \\
Pembelajaran tematik terpadu & Miles dan Huberman. Hasil dari penelitian ini menunjukkan bahwa langkah- \\
Kurikulum 20I3 & langkah pembelajaran berbasis masalah di SDN 04 Aikmel, yaitu: (a) orientasi \\
& siswa pada masalah,(b) mengorganisasikan siswa untuk belajar, (c) membimbing \\
& pengalaman individu/kelompok, (d) mengembangkan dan mempresentasikan \\
& hasil diskusi, dan (e) menganalisis dan mengevaluasi proses pemecahan masalah. \\
& Adapun saran peneliti terhadap guru adalah agar lebih memperluas cakupan dan \\
mengembangkan materi ajar.
\end{tabular}

\section{Pendahuluan}

Saat ini Indonesia sedang menerapkan kurikulum 2013 yang memandang pembelajaran merupakan proses ilmiah, oleh karena itu pembelajaran pada kurikulum 2013 untuk semua jenjang pendidikan menggunakan pendekatan saintifik/ilmiah. Hal ini sesuai dengan Permendikbud No. I03 tahun 2014 tentang pembelajaran pada pendidikan dasar dan pendidikan menengah dinyatakan bahwa pembelajaran pada Kurikulum 2013 menggunakan pendekatan saintifik atau pendekatan berbasis proses keilmuan. Pendekatan saintifik dapat menggunakan beberapa strategi seperti pembelajaran kontekstual. Model pembelajaran merupakan suatu bentuk pembelajaran yang memiliki nama, ciri, sintak, pengaturan, dan budaya misalnya discovery learning, project based learning, problem based learning, inquiry learning.

Perbedaan kurikulum 2013 dengan kurikulum sebelumnya pada jenjang pendidikan dasar (SD) adalah skema pembelajaran tematik terpadu yang diterapkan. Apabila pada kurikulum sebelumnya, skema tematik diterapkan pada kelas satu hingga tiga. Sedangkan pada Kurikulum 2013, pola Tematik Terpadu diterapkan di kelas satu hingga enam. Pembelajaran tematik terpadu merupakan pendekatan pembelajaran yang memadukan berbagai kompetensi dari berbagai mata pelajaran ke dalam berbagai tema (Majid,20I4:49). Dengan adanya pemaduan antar mata pelajaran maka peserta didik akan memperoleh pengetahuan dan keterampilan secara utuh sehinga pembelajaran akan jadi lebih bermakna bagi peserta didik. Bermaka artinya peserta didik akan memahami konsep-konsep melalui pengalaman langsung dan nyata yang menghubungkan konsep antar-mata pelajaran.

Dalam melaksanakan pembelajaran tematik disekolah dasar, dengan pendekatan saintifik, maka pendekatan saintifik perlu dipadukan dengan modelmodel pembelajaran pendekatan saintifik lainnya yang sesuai dengan kurikulum yang berlaku, salah satunya yaitu model pembelajaran berbasis masalah. Model pembelajaran berbasis masalah dapat memfokuskan siswa dengan mengarahkan siswa menjadi pemelajar yang mandiri dan terlibat langsung secara aktif dalam proses pembelajaran baik secara individu maupun kelompok.

Pembelajaran berbasis masalah merupakan suatu pendekatan pembelajaran yang memberikan pengalaman otentik yang mendorong peserta didik peserta didik belajar aktif mengkonstruksi pengetahuan dan mengintegrasikan konteks belajar 
disekolah dan belajar dikehidupan nyata secara alamiah. Moffit (dalam Rusman 2012:24I) mengemukakan bahwa pembebelajaran berbasis masalah merupakan suatu pendekatan pembelajaran yang menggunakan masalah dunia nyata sebagai konteks bagi siswa untuk belajar berpikir kritis dan keterampilan pemecahan masalah serta untuk memperoleh pengetahuan dan konsep yang esensi dari materi pelajaran.

Tujuan penelitian ini adalah: Untuk mendeskripsikan implementasi Model Pembelajaran Berbasis Masalah pada pembelajaran tematik terpadu kurikulum 2013 di kelas tinggi SDN 04 Aikmel.

\section{Metode}

Jenis penelitian ini adalah penelitian kualitatif. Peneltian kualitatif menurut Bogdan \& Taylor (dalam Moleong 2010:4) adalah prosedur penelitian yang menghasilkan data deskriptif berupa kata-kata atau lisan dari dari orang-orang dan perilaku yang diamati. Penelitian ini berusaha untuk mendeskripsikan hasil implementasi pembelajaran berbasis masalah pada pembelajaran tematik terpadu kurikulum 2013 di kelas tinggi SDN 04 Aikmel.

Dalam penelitian ini peneliti bertindak sebagai pengelola instrumen yang berarti peneliti bertindak sebagai pengamat dan mengumpulkan data yang diperlukan dan melaporkan hasil penelitian. Peneliti mengamati dan mendokumentasikan proses kegiatan pembelajaran menggunakan model pembelajaran berbasis masalah pada kelas tinggi SDN 04 Aikmel.

Penelitian ini dilaksanakan di kelas tinggi SDN 04 Aikmel, yang terletak di desa Aikmel, Kabupaten Lombok Timur. Alasan memilih sekolah ini karena SDN 04 Aikmel telah menerapkan kurikulum 2013. Waktu penelitian ini dilaksanakan pada bulan april 2018.

Teknik analisis data yang digunakan dalam penlitian ini adalah menggunakan teknik model Miles dan huberman. Menurut Miles dan Huberman (dalam Sugiyono 2013:337) mengemukakan bahwa aktivitas dalam analisis data kualitatif dilakukan secara interaktif, dan berlangsung secara terus menerus sampai tuntas, sehingga datanya sudah jenuh.

\section{Hasil dan pembahasan}

Pada kegiatan pembelajaran di kelas IV, guru menggunakan tema 9 (Makananku sehat dan bergizi), subtema 2 (Manfaat Makanan sehat dan bergizi), pada pembelajaran 5, dan Adapun deskripsi kegiatan pembelajaran yang dilakukan oleh guru dengan menggunakan model pembelajaran berbasis masalah yaitu sebagai berikut.

\section{Orientasi Siswa pada Masalah}

Pada tahap ini, sebelum memulaia kegiatan pembelajaran, guru mengajak siswa menyanyikan lagu "aku anak sehat" dengan tujuan untuk membangkitkan semangat siswa dalam pembelajaran. Setelah menyanyikan lagu, guru mengulas sedikit materi yang di bahas pada pertemuan sebelumnya dan mengaiktkannya dengan pembelajaran yang akan dilakukan hari ini. Lalu di lanjutkan dengan kegiatan apersepsi tentang materi yang akan di ajarkan.

Guru : Pak Un ingin tahu dulu, sipa yang bisa jawab, makanan yang sehat dan bergizi itu yang bagaimana?

Siswa : yang seimbang, yang bergizi, makanan yang mengandung vitamin, karbohidrat, protein, mineral dan lemak

Guru : ya bagus sekali, makanan yang mengandung vitamin, karbohidrat, protein, mineral dan lemak. Trus di sempurnakan dari jawaban seimbang tadi, maksudnya bagaiman seimbang?

$\begin{array}{ll}\text { Siswa } & \text { : siswa terdiam } \\ \text { Guru } & \text { : baiklah sekarang kita akan bahas }\end{array}$ tentang makan sehat bergizi dan seimbang

Setelah itu, guru menjelaskan tujuan pembelajaran yang akan dicapai oleh siswa setelah mengikuti kegiatan pembelajaran. Selanjutnya menjelaskan materi tentang gizi seimbang dengan menunjukkan gambar grafik lingkaran yang menunjukkan jumlah nutrisi yang sebaiknya dikonsumsi setiap hari.

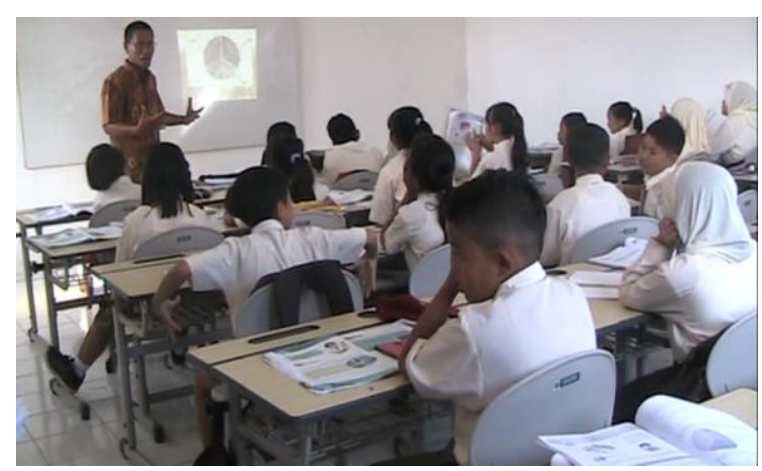

Gambar I. Guru menjelaskan materi pembelajaran

Setelah guru menjelaskan materi pembelajaran, guru mulai melibatkan siswa dalam permasalahan dengan memberikan pertanyaan "Udin ingin mengetahui berapa banyak gizi yang sebaiknya dikonsumsi setiap hari untuk menjaga kesehatan tubuh.?" Kemudian guru menampilkan gambar tabel tentang jumlah nutrisi ideal dalam bilangan persen yaitu karbohidrat 30\%, vitamin 35\%, prtotein $15 \%$, mineral $15 \%$, dan lemak 5\% dan meminta siswa mengubahnya menjadi bilangan pecahan. 
Setelah siswa mengetahui jumlah persentase gizi dari setiap makanan, guru memberikan permasalahan, yaitu "Jika dalam sehari total kalori yang diperlukan tubuh adalah 2.500 kalori, berapakah jumlah ideal dari masing-masing gizi yang perlu dikonsumsi setiap harinya?

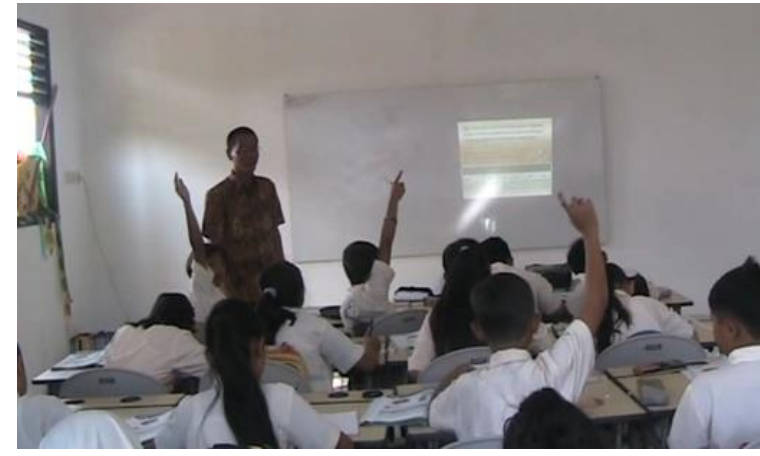

Gambar 2. Guru melibatkan siswa dalam pemecahan masalah

Selain permasalahn yang harus diseleisaikan secara individu, guru juga memberikan tugas kepada setiap kelompok yaitu membuat diagram lingkaran kemudian mengirisnya sesuai dengan jumlah nutrisi dari setiap makanan yang ada pada tabel yaitu karbohidrat $30 \%$, vitamin $35 \%$, protein $15 \%$, mineral I5\% dan lemak 5\%.

\section{Mengorganisasikan Siswa untuk Belajar}

Pada tahap ini kegiatan yang dilakuka oleh guru yaitu menjelaskan bagaimana cara mengubah bilangan persen menjadi bilangan pecahan kepada siswa, hal ini bertujuan agar siswa bisa menyelasikan tugas yang akan diberikan selanjutnya oleh guru yaitu siswa diminta untuk menghitung jumlah total kalori yang di butuhkan oleh tubuh manusia dengan tujuan agar dalam kehidupan sehari-hari siswa siswa bisa mengkonsumsi makanan sesuai degan jumlah gizi yang dibutuhkan oleh tubuh.

Sedangkan untuk membuat diagram lingkaran dan mengiris diagram tersebut sesuai dengan jumlah kandungan gizi makanan, menginformasikan kepada setiap kelompok untuk membuat lingkaran menggunakan jangka supaya siswa lebih mudah menemukan titik tengah dari lingkaran tersebut dan supaya siswa lebih mudah mengiris lingkaran sesuai dengan jumlah kandungan gizi makanan.

\section{Membimbing Pengalaman Individu /Kelompok}

Pada tahap ini, membimbing siswa untuk menggunakan penggaris busur derajat untuk supaya bisa mengiris lingkarang sesuai dengan jumlah. bagiannya. Kemudian guru meminta siswa melakukan experiment menghitung besarnya bagian irisan lingkaran sesuai dengan jumlah kandungan gizi makanan, guru meminta setiap kelompok untuk menghitung dan mendiskusikan jwaban mereka.

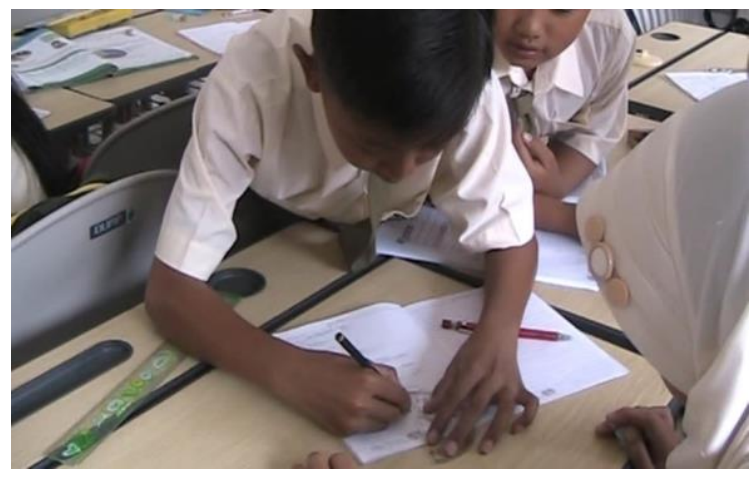

Gambar 3. Siswa mengiris lingkaran sesuai dengan jumlah gizi makanan

\section{Mengembangkan dan mempresentasikan hasil diskusi}

Selanjutnya setelah semua siswa selesai mengerjakan tugas kelompok, guru meminta perwakilan dari setiap kelompok untuk mempresentasikan hasil diskusinya didepan kelas.

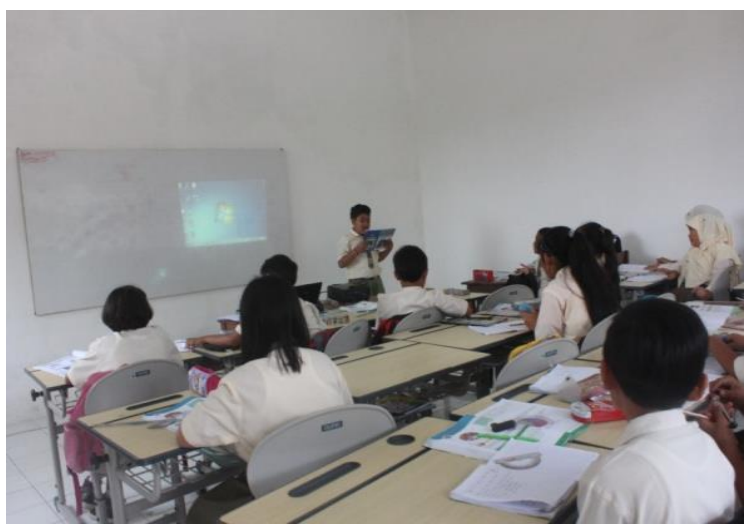

Gambar 4. Siswa mempresentasikan hasil diskusi

\section{Menganalisis dan mengevaluasi proses pemecahan masalah}

Pada tahap ini, siswa dengan bimbingan guru menyimpulkan pembelajaran yang telah dilakukan hari ini, lalu dilanjutkan dengan guru memberikan soal evaluasi kepada siswa untuk mengetahui pemahan siswa tentang materi yang telah diajarkan oleh guru.

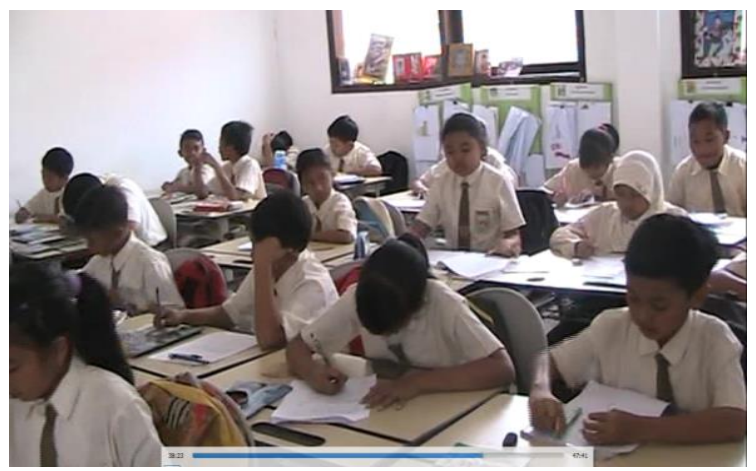

Gambar 5. Siswa mengerjakan soal evaluasi 
Berdasarkan paparan di atas, didapatkan langkah-langkah pembelajaran berbasis masalah pada pembelajaran tematik terpadu kurikulum 2013 di kelas tinggi SDN 04 Aikmel, yaitu: (I) orientasi siswa pada masalah,(2) mengorganisasikan siswa untuk belajar, (3) membimbing pengalaman individu /kelompok, (4) mengembangkan dan mempresentasikan hasil diskusi, dan (5) menganalisis dan mengevaluasi proses pemecahan masalah.

Pelaksanaan pembelajaran berbasis masalah di SDN 04 Aikmel tersebut sesuai dengan pendapat Ibrahim dan Nur (2000) langkah-langkah yang ditempuh dalam penggunaan pembelajaran berbasis masalah sebagai berikut.

Tabel I. Langkah-langkah pembelajaran berbasis masalah

\begin{tabular}{|c|c|c|}
\hline Fase & Indikator & Tingkah Laku Guru \\
\hline I & Orientasi siswa pada masalah & $\begin{array}{l}\text { Menjelaskan tujuan pembelajaran, menjelaskan logistik yang } \\
\text { diperlukan, dan memotivasi siswa terlibat dalam pemecahan masalah }\end{array}$ \\
\hline 2 & Mengorganisasi siswa untuk belajar & $\begin{array}{l}\text { Membantu siswa mendefinisikan dan mengorganisasikan tugas } \\
\text { belajar yang berhubungan dengan masalah tersebut }\end{array}$ \\
\hline 3 & $\begin{array}{l}\text { Membimbing } \\
\text { individual/kelompok }\end{array}$ & $\begin{array}{l}\text { Mendorong siswa untuk mengumpulkan informasi yang sesuai, } \\
\text { melaksanakan eksperimen untuk mendapatkan penjelasan dan } \\
\text { pemecahan masalah }\end{array}$ \\
\hline 4 & $\begin{array}{l}\text { Mengembangkan dan menyajikan } \\
\text { hasil karya }\end{array}$ & $\begin{array}{l}\text { Membantu siswa dalam merencanakan dan menyiapkan karya yang } \\
\text { sesuai seperti laporan, dan membantu mereka untuk berbagi tugas } \\
\text { dengan temannya }\end{array}$ \\
\hline 5 & $\begin{array}{l}\text { Menganalisis dan mengevaluasi } \\
\text { proses pemecahan masalah }\end{array}$ & $\begin{array}{l}\text { Membantu siswa untuk melakukan refleksi atau evaluasi terhadap } \\
\text { penyelidikan mereka dan proses yang mereka gunakan. }\end{array}$ \\
\hline
\end{tabular}

\section{Simpulan}

Berdasarkan hasil penelitian, maka dalam penelitian ini didapatkan ksimpulan bahwa langkahlangkah penerapan model pembelajaran berbasis masalah pada pembelajaran tematik terpadu kurikulum 2013 di kelas tinggi SDN 04 Aikmel, yaitu: (I) orientasi siswa pada masalah,(2) mengorganisasikan siswa untuk belajar, (3) membimbing pengalaman individu /kelompok, (4) mengembangkan dan mempresentasikan hasil diskusi, dan (5) menganalisis dan mengevaluasi proses pemecahan masalah.

Berdasarkan kesimpulan, diajukan saran yang dapat dipertimbangkan dalam meningkatkan pelaksanaan pembelajaran dengan model pembelajaran berbasis masalah pada pembelajaran tematik terpadu kurikulum 2013, yaitu agar guru lebih memperluas cakupan dan pengembangan materi. Misalnya selain memberikan tugas pada siswa untuk mengarsir lingkaran, siswa juga ditugaskan untuk mengidentifikasi makanan yang mengandung karbohidrat, vitamin, protein, mineral dan lemak. Dengan demikian pembelajaran tematik yang diterapkan akan lebih komprehensif.

\section{Referensi}

Abdul Majid. (20I4). Strategi Pembelajaran. Bandung: PT Remaja Rosdakarya

Ibrahim, M. dan Nur, M. (2000). Pengajaran Berdasarkan Masalah. Surabaya: Unesa University Press.

Kemendikbud. (2014). Permendikbud Nomor IO3 Tahun 2014 Tentang Pembelajaran Pada Pendidikan Dasar dan Pendidikan Menengah. Jakarta: Kementerian Pendidikan dan Kebudayaan RI.

Moleong, Lexy J. (2010). Metodologi penelitian kualitatif. Bandung: Remaja Rosdakarya.

Rusman, 2012. Model-model Pembelajaran: Mengembangkan Profesionalisme Guru. Jakarta: Raja Grafindo Persada

Sugiyono. 2013. Metode Penelitian Pendidikan Pendekatan Kuantitatif, Kualitatif, dan R\&D. Bandung: Alfabeta. 